\title{
The impact of a catastrophic storm event on benthic macroinvertebrate communities in upland headwater streams and potential implications for ecological diversity and assessment of ecological status
}

\author{
Hugh B. FEELEY, ${ }^{1 *}$ Stephen DAVIS, ${ }^{1}$ Michael BRUEN, ${ }^{2}$ Sean BLACKLOCKE, ${ }^{2}$ Mary KELLY-QUINN ${ }^{1}$
}

${ }^{1}$ Freshwater Biodiversity, Ecology and Fisheries Research Group (freBEF), UCD School of Biology and Environmental Science, Science Education and Research Centre (West), University College Dublin, Belfield, Dublin 4, Ireland; ${ }^{2}$ UCD School of Civil, Structural and Environmental Engineering, University College Dublin, Newstead, Belfield, Dublin 4, Ireland

*Corresponding author: hughfeeley@gmail.com

\begin{abstract}
Upland headwater streams are dynamic systems, responding rapidly to changes in climatic conditions. This study examined the effects of a catastrophic rainfall event, that occured on 24 October 2011 on the east coast of Ireland, on the macroinvertebrate community composition and structure of four headwater streams in the river Liffey catchment located in the Wicklow Mountains. The ecological status before and after the storm were also evaluated. The water level and pH of each stream were recorded using continuous monitoring equipment, while rainfall data for the study period were sourced from a local weather station. Benthic macroinvertebrates were investigated before and after the storm event using Surber sampling. Results showed rapid and large increases in water level and significant declines in stream $p H$ in response to intensive rainfall during the storm. The high water levels also caused major physical damage and abrasion in all four streams, that significantly altered instream habitats. The storm event induced significant losses to the richness and/or density of most taxonomic groups, with the exception of the Plecoptera. Furthermore, the overall community composition and structure changed significantly, most likely as a result of physical disturbance, given the relative persistence of acid-sensitive taxa and the relatively short period of harsh acidic conditions $(<5 \mathrm{pH})$. Interestingly however, the ecological status of each of the four study sites, tested using the Small Stream Risk Score (SSRS), the Biological Monitoring Working Party (BMWP) and the Average Score Per Taxon (ASPT) indices, was unaltered by the loss in richness and densities. This was likely a result of the maintenance of plecopteran richness and the absence of organic pollution, thus highlighting the need to develop appropriate indices to assess the ecological status of streams and rivers affected by physical disturbance caused by large storm events. Ultimately, catastrophic storm events in upland headwater streams have potentially major implications for the maintanence of regional macroinvertebrate diversity within affected regions.
\end{abstract}

Key words: acidification, bioassessment, biodiversity, climate, disturbance, Ireland.

Received: March 2012. Accepted: May 2012.

\section{INTRODUCTION}

Upland headwater streams are typically dynamic and changeable habitats, highly susceptible to rapid increases in flow during periods of heavy rainfall (Resh et al., 1988). The frequency, amount and intensity of rainfall, together with antecedent climatic conditions have been shown to influence the magnitude, duration and nature of episodic stream acidification occurring during such highflow conditions (Ormerod et al. 1989; Kelly-Quinn et al. 1996; Kowalik et al. 2007). This in turn has been shown to affect benthic macroinvertebrate survival in such streams (Tierney et al., 1998; Lepori et al., 2003; Kowalik and Ormerod 2006; Tixier et al., 2009; Feeley et al., 2011). Furthermore, the increased discharges and velocities, and the resultant disturbance and movement of the streambed substrates during high-flow events alter macroinvertebrate community composition and structure within streams, especially during the peaks of high-flow periods (Robinson and Minshall, 1986; Brittain and Eikland, 1988; Resh et al., 1988; Death, 2003). As a result, the interaction between the magnitude, duration and frequency of storm events is a major factor in species survival (Giller et al., 1991; Weatherley and Ormerod, 1991; McCabe and Gotelli, 2000).

The composition and structure of macroinvertebrate communities in dynamic streams is relative to natural disturbance cycles (i.e. high flow events) (Resh et al., 1988; Townsend, 1989; Giller et al., 1991). For example, streams affected by episodic acidity (i.e. intermittent periods of low $\mathrm{pH}$ ) will be dominated by acid-tolerant communities, with some acid-sensitive taxa surviving low $\mathrm{pH}$ by burrowing into the streambed and/or drifting downstream, the latter leading to periods of ecological impact (Ormerod et al., 1987; Tixier and Guérold, 2005; Gibbons et al., 2010; Feeley et al., 2011). Nevertheless, the effects of inordinately large storm events are more difficult to predict due to the severity, magnitude, spatial extent and rarity of such disturbances relative to the durations of benthic macroinvertebrate life cycles in lotic systems (Turner and Dale, 1998; Snyder and Johnson, 2006). Such events 
have been shown to be responsible for reductions in both benthic macroinvertebrate richness and density, as macroinvertebrates are not typically equipped to survive these catastrophic disturbances (Giller et al., 1991; Boulton and Lake, 1992; Lake, 2000; Synder and Johnson, 2006; Death, 2008). In Ireland, Giller et al. (1991) previously found that a catastrophic storm event (one in fifty year event) followed by several lesser flood events resulted in significant and long lasting impacts on the macroinvertebrate communities within the Araglin catchment in county Cork in the south of Ireland.

On 24 October 2011 a significant rainfall event (one in twenty to one in twenty five-year event: Mac Cárthaigh, 2011) occurred on the east coast of Ireland. This paper presents the results of an investigation of the impacts of that storm event on the benthic macroinvertebrate communities of four upland headwater streams in the Wicklow Mountains within the effected region. It also examines the ecological status of the four study streams before and after the storm and discusses the possible implications for status assessment and biodiversity of streams that have been exposed to such catastrophic storm events.

\section{METHODS}

Four headwater streams in county Wicklow were monitored over a four-month period from August 2011 to November 2011 (Fig. 1). The streams sampled included the Cransilliagh Brook (WM1), a tributary of the river Liffey (WM2), and the Ballyknocken (WM10) and Fraughan (WM11) brooks, both tributaries of Poulaphouca Reservoir (Fig. 1). The streams are either second or third order streams, with catchments ranging in size from 0.41 to 1.93 $\mathrm{km}^{2}$, and the study sites were situated between 221 and $377 \mathrm{~m}$ in altitude (Tab. 1). All streams drain igneous (granite/felsite) geology and either blanket peat or poorly drained, peaty mineral soils (Tab. 1). Two streams drained semi-natural moorland (sites WM2 and WM11) areas and two drained plantation conifer forest (sites WM1 and WM10) (Tab. 1). The moorlands consisted of open landscapes generally dominated by purple moor grass (Molinia caerulea (L.) Moench), and heather (Calluna vulgaris (L.) Hull), with riparian banks dominated mainly by rushes (e.g. Juncus spp.) and gorse (Ulex europaeus L.). The forested streams drained catchments with approximately $30-35 \%$ conifer forest cover that did not create any significant shading. All streams sampled are low conductivity waters $(<200 \mu \mathrm{S} / \mathrm{cm})$.

In August 2011 each study stream was equipped with a WTW field continuous $\mathrm{pH}$ probe and a submerged pressure recorder (diver from Schlumberger Water Services, www.slb.com). WM1 was also equipped with a terrestrial diver to measure variations in atmospheric pressure. Changes in stream water levels were measured by subtracting the difference in pressure between the atmosphere

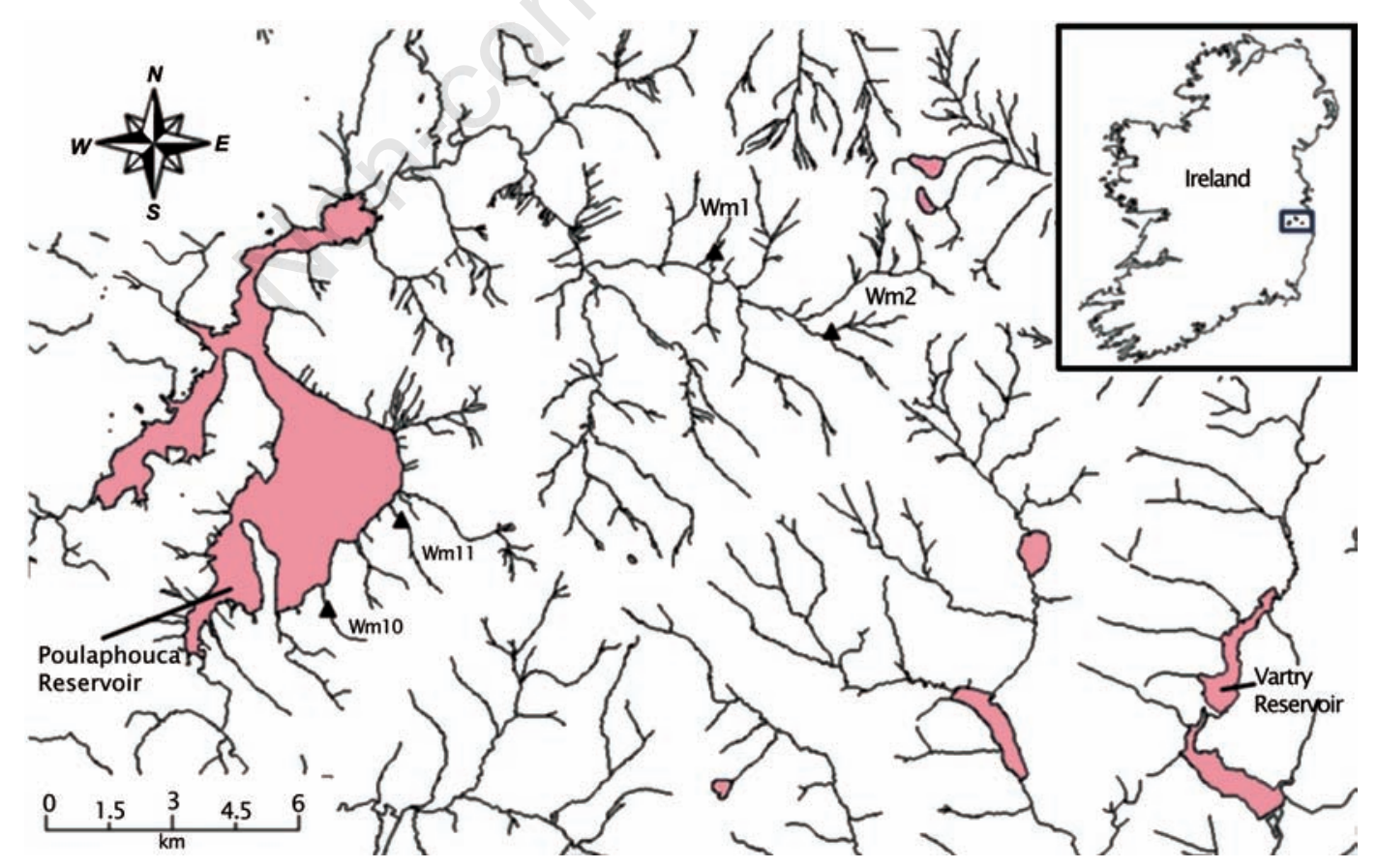

Fig. 1. Location of the four study streams in the Wicklow Mountains on the east coast of Ireland. Wm1, Cransilliagh brook; Wm2, tributary of the Liffey river; Wm10, Ballyknocken brook; Wm11, Fraughan brook. 
and the submerged diver at each study stream and converting to an equivalent depth of water. Both devices recorded data at 5-min intervals. These data were collected during the catastrophic storm of 24 October 2011. However, some data were lost because some devices were damaged by the flood and some were discarded, e.g. the $\mathrm{pH}$ and water level data from streams WM1 and WM10, and the $\mathrm{pH}$ data from stream WM2 were deemed unreliable. The retrievable data from WM1, WM2 and WM10 were relatively similar to that of WM11 preceding the major storm event and therefore, only the full data set (i.e. both water level and $\mathrm{pH}$ ) for WM11 is shown below. The rainfall data were sourced from Casement Aerodrome in south country Dublin, approximately 25 to $30 \mathrm{~km}$ north of sampling locations and were provided by Met Éireann (www.met.ie). The physical disturbance caused to each stream during the storm event was not measured quantitatively. However, the disturbance was visually assessed using before and after photographs (Fig. 2). For consistency with the water level and pH data only WM11 is shown below. Both photographs were taken facing upstream.

Macroinvertebrates were sampled at each site on two occasions, the first on 10 August 2011 before the storm
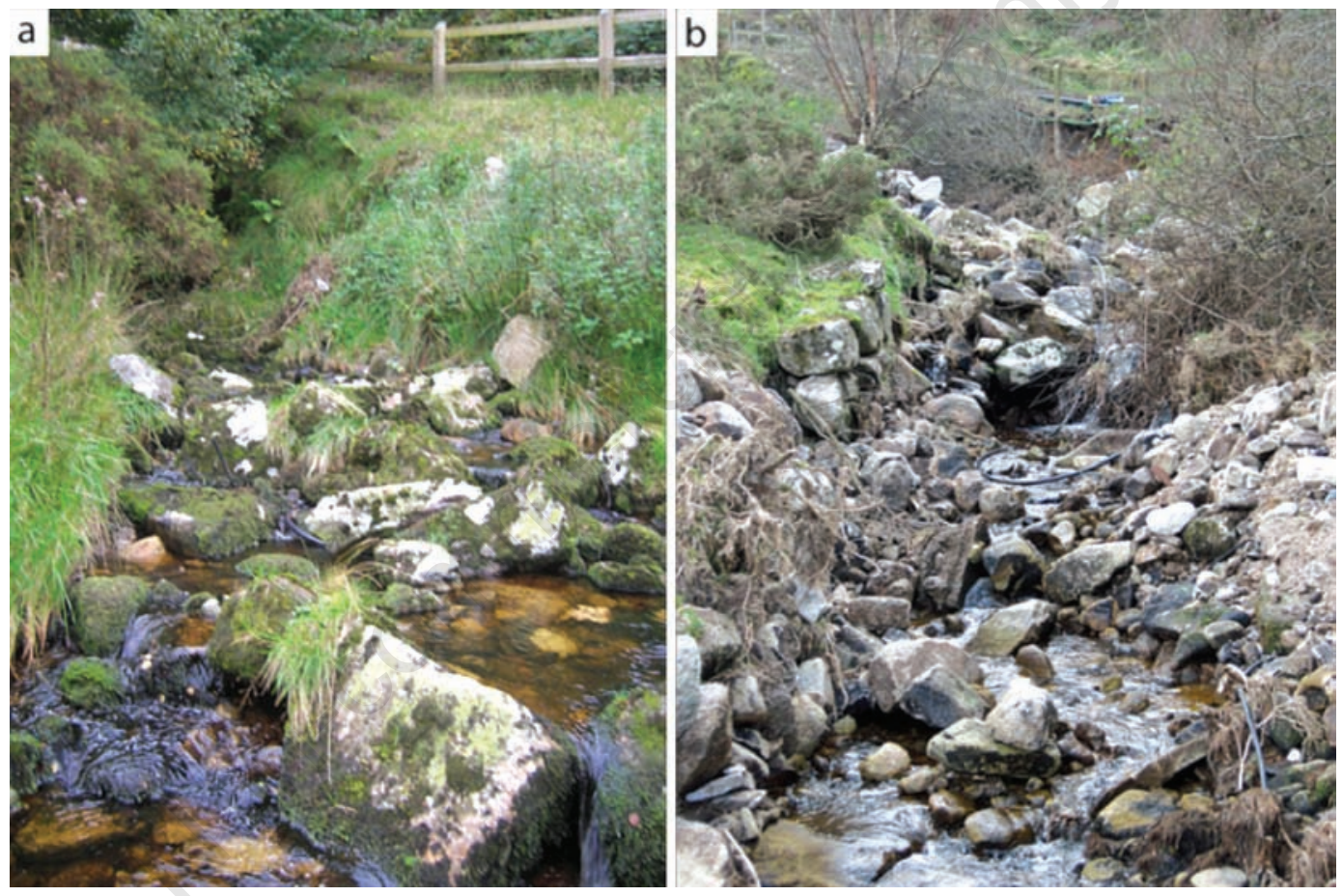

Fig. 2. Upstream photographs of the study stream before (a) and after (b) the catastrophic storm event at Fraughan Brook (WM11) in the Wicklow Mountains.

Tab. 1. Stream sites sampled during the period August 2011 to November 2011, including site code, location and physical characteristics.

\begin{tabular}{|c|c|c|c|c|c|c|c|c|c|c|c|}
\hline Stream name & $\begin{array}{l}\text { Site } \\
\text { code }\end{array}$ & Longitude & Latitude & Order & $\begin{array}{l}\text { Elevation } \\
\text { (m asl) }\end{array}$ & $\begin{array}{c}\text { Catchment } \\
\text { size } \\
\left(\mathrm{km}^{2}\right)\end{array}$ & $\begin{array}{l}\text { Stream } \\
\text { width } \\
(\mathrm{m})^{*}\end{array}$ & $\begin{array}{c}\text { Mean } \\
\text { catchment } \\
\text { slope } \\
\text { (degrees) }\end{array}$ & Soil & Geology & Land use \\
\hline Cransilliagh Brook & WM1 & $6^{\circ} 22^{\prime} 15.82^{\prime \prime} \mathrm{W}$ & $53^{\circ} 10^{\prime} 4.23^{\prime \prime} \mathrm{N}$ & 2 & 339 & 0.41 & 2 & 9.72 & BktPt & $\mathrm{Gr} / \mathrm{F}$ & Forest \\
\hline Tributary of river Liffey & WM2 & $6^{\circ} 19^{\prime} 59.40^{\prime \prime} \mathrm{W}$ & $53^{\circ} 9^{\prime} 4.83^{\prime \prime} \mathrm{N}$ & 3 & 377 & 1.93 & 3 & 5.01 & $\mathrm{BktPt}$ & $\mathrm{Gr} / \mathrm{F}$ & Moor \\
\hline Ballyknocken Brook & WM10 & $6^{\circ} 30$ ' 15.92” W & $53^{\circ} 5^{\prime} 52.10 \mathrm{~N}$ & 2 & 221 & 1.13 & 2 & 12.0 & AminSRPT & $\mathrm{T} \mathrm{Gr} / \mathrm{F}$ & Forest \\
\hline Fraughan Brook & WM11 & $6^{\circ} 28^{\prime} 44.84^{\prime \prime} \mathrm{W}$ & $53^{\circ} 6^{\prime} 55.48^{\prime \prime} \mathrm{N}$ & 2 & 227 & 0.84 & 3 & 11.2 & AminSRPT & $\mathrm{T} \quad \mathrm{Gr} / \mathrm{F}$ & Moor \\
\hline
\end{tabular}

"Approximate width at sampling point; $m$ asl, metre above sea level; forest, conifer forest plantation; moor, moorland; BktPt, blanket peat; aminSRPT, peaty lithosolic-podzolic soils; Gr/F, granitelfelsite. 
and the second on 8 November 2011 after the storm, using six replicate Surber samples (area $0.09 \mathrm{~m}^{2}$, mesh size 250 $\mu \mathrm{m})$, three in the margins and three in the riffle habitats, within each study stream. The positioning of the Surber sampler was selected using random number tables. All samples were preserved using $70 \%$ industrial methylated spirits. In the laboratory, each sample was sorted after being washed through a $250 \mu \mathrm{m}$ sieve. All samples sorted were independently assessed as part of routine quality control (i.e. full removal of all individual taxa) (Haase et al., 2006; Feeley et al., 2012). The Ephemeroptera, Plecoptera and Trichoptera were identified to genus-level, while Diptera, Coleoptera, Odonata, Mollusca and Hemiptera were identified to family level using standard Freshwater Biological Association identification keys. All other taxa were identified to the lowest feasible taxonomic level. Standardised taxon lists were produced and used to calculate mean taxonomic richness and densities, and mean richness and density of the Plecoptera, Ephemeroptera, Coleoptera and Diptera. These data were then tested for normality using Kolmogorov-Smirnov tests and pre and post storm values were compared using non-parametric Wilcoxon signed rank tests in PASW Statistics 18 (IBM SPSS Inc. 2010). The overall change in macroinvertebrate composition and structure was visualised using Cluster analysis dendograms based on Bray-Curtis similarities of untransformed data (PRIMER 6.1.12: Clarke and Gorley, 2006). Similarity profiles (SIMPROF) tests (PRIMER 6.1.12: Clarke and Gorley, 2006) were used to indicate significant a priori unstructured hierarchical groupings $(\mathrm{P}<0.05)$ of similar macroinvertebrate community composition and structure between streams on both sampling dates (i.e. before and after the catastrophic storm event).

Finally, the effect of the catastrophic storm was examined using macroinvertebrate metrics which assess the ecological status of each site based on the scoring of sensitive taxa at family level. The three metrics calculated were the Small Stream Risk Score (SSRS) (Anonymous, 2005; Kavanagh et al., 2006), the Biological Monitoring Working Party (BMWP) Score and the Average Score Per Taxon (ASPT) (Hawkes, 1997), previously used in headwater stream assessment in Ireland (Callanan et al., 2008; Feeley et al., 2012). The before and after storm metric data were then tested for normality using KolmogorovSmirnov tests and compared using paired $t$-tests in PASW Statistics 18 (IBM SPSS, 2010).

\section{RESULTS}

\section{Rainfall, water level, $\mathrm{pH}$ and physical disturbance}

Daily rainfall amounts at Casement Aerodrome from August to early November 2011 ranged from 0 to $27 \mathrm{~mm}$, with a mean of $2 \mathrm{~mm}$ day $^{-1}$ falling during the study period (Fig. 3a). The exception to this was the rainfall event of
24 October when $83 \mathrm{~mm}$ fell in a 24-h period (Fig. 3a). During this catastrophic event the majority of rainfall (65.8 $\mathrm{mm}$ ) fell over a 4-h period (15.00-19.00 h), with $36.1 \mathrm{~mm}$ falling between 15.00 and $19.00 \mathrm{~h}$ and a 60 -min maximum of $18.2 \mathrm{~mm}$ falling between 16.00 and $17.00 \mathrm{~h}$. Three other noteable total daily rainfall events occurred preceeding the catastrophic event, the first and second on 30 September
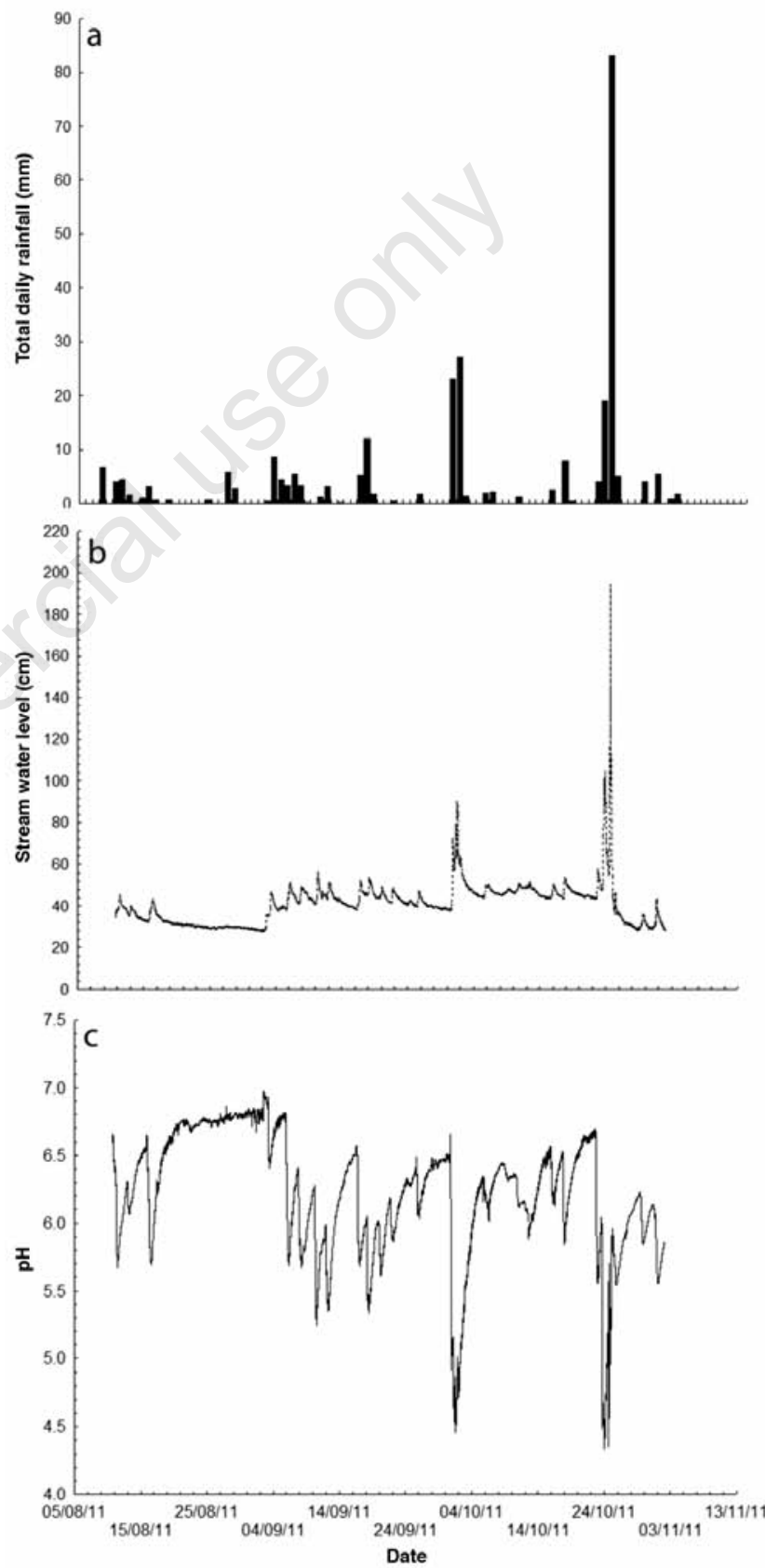

Fig. 3. a) The rainfall ( $\mathrm{mm})$ recorded at Casement weather station; b) the change in water level at Fraughan Brook (cm); c) $\mathrm{pH}$ at Fraughan brook (WM11) in the Wicklow Mountains from August to November 2011. 
(23 $\mathrm{mm}$ ) and 1 October $(27 \mathrm{~mm})$ respectively, and the third on 23 October $(19 \mathrm{~mm})$ immediately prior the catastrophic rainfall event of 24 October (Fig. 3a).

Over the course of the study, stream water levels mirrored rainfall, with notable increases occurring when daily rainfall amounts were $>20 \mathrm{~mm}$ (Fig. 3b). During the study period the most substantial change in water level occured between 23 and 25 October, with the highest water level change occuring on 24 October (Fig. 3b). Water levels began to rise on 23 October increasing rapidly by $102.8 \mathrm{~cm}$ before dropping back to $54.9 \mathrm{~cm}$ and then rising again around midday on 24 October, with the peak of the flood occurring at approximately $17.00 \mathrm{~h}$ (194.2 $\mathrm{cm})$ before slowly receeding to circum-normal levels $(<40 \mathrm{~cm})$ shortly after $02.00 \mathrm{~h}$ on 25 October (Fig. 3b). The peak water level was more than $450 \%$ that of mean normal stream water levels $(\sim 35 \mathrm{~cm})$ preceeding the catastrophic event (Fig. 3b). Similar results were found at WM2, with a peak high water level of $128.2 \mathrm{~cm}$ at $19.50 \mathrm{~h},>500 \%$ the mean water level $(20.9 \mathrm{~cm})$ (Fig. 3b). No reliable data were recorded at WM1 and WM10 due to probe damage.

The baseflow $\mathrm{pH}$ of all four study streams was generally circumneutral ( $\sim 6$ to $7 \mathrm{pH})$, and decreased with increases in rainfall and stream water levels. The changes in $\mathrm{pH}$ in stream WM11 highlights the episodic acidic nature of the stream in response to the increased rainfall and water levels, with a minimum $\mathrm{pH}(\leq 4.5 \mathrm{pH})$ recorded on three occasions during this study period (Fig. 3c). These occurred on 1 October, and again in quick succession on 23 and 24 October of during the catastrophic storm event (Fig. 3c). The lowest $\mathrm{pH}(4.35 \mathrm{pH})$ was recorded at 15.25 $\mathrm{h}$ on 24 October (Fig. 3c). Unfortunately, no $\mathrm{pH}$ data could be reliably interpreted from WM1, while no $\mathrm{pH}$ data were received from WM2 and WM10 due to loss of equipment.

The instream characteristics of all four study streams before the storm event on 24 October reflected natural, stabilised riffle-run sequences, interspersed with shallow pools (Fig. 2a). All four streams were generally dominated by cobbles with some coarse gravel and sand, interspersed with a few large boulders (Fig. 2a). Instream vegetation consisted of algae, mosses and grasses. However, the post storm photograph indicates the magnitude of the instream disturbance caused by the high rainfall and increased water levels (Fig. 2b). The streambed experienced downcutting and extreme scouring, removal of most instream vegetation and an influx of boulders and coarse substrates (Fig. 2b). Furthermore, the stream banks were extremely eroded and destabilised (Fig. 2b), a characteristic noted across all four streams, with two streams (WM1 and WM10) altering their course for short distances ( $\sim 2$ to 5 m) at several points along their course.

\section{Effects on macroinvertebrates}

Taxon richness of the four study sites changed significantly $(\mathrm{P}<0.001)$ between August and November 2011 (Tab. 2). The total density of macroinvertebrates was also significantly reduced $(\mathrm{P}<0.001)$ on average by over $85 \%$ between the two sampling dates with average densities dropping from 2195 individuals $\mathrm{m}^{-2}$ to 323 individuals $\mathrm{m}^{-2}$ (Tab. 2). Changes in specific macroinvertebrate groups were more variable. Both plecopteran richness and density were not significantly $(\mathrm{P}>0.05)$ altered, with richness increasing slightly from 3 to 3.5 taxa $0.09 \mathrm{~m}^{-2}$ even though densities dropped by over $53 \%$ on average (Tab. 2). Similarly ephemeropteran richness did not significantly change $(\mathrm{P}>0.05)$. However, ephemeropteran density across the four

Tab. 2. Paired Wilcoxon signed rank tests comparing the mean $( \pm \mathrm{SE})$ of selected macroinvertebrate richness and density scores before (pre) and after (post) the catastrophic storm event on the $24^{\text {th }}$ of October 2011 in the Wicklow Mountains.

\begin{tabular}{|c|c|c|c|c|}
\hline Scores & $\begin{array}{c}\text { Pre-storm } \\
(\text { mean } \pm \mathrm{SE})\end{array}$ & $\begin{array}{l}\text { Post-storm } \\
(\text { mean } \pm \mathrm{SE})\end{array}$ & $\begin{array}{c}Z \\
(n=24)\end{array}$ & $\mathrm{P}$ value \\
\hline Taxon richness $^{\circ}$ & $13.7( \pm 0.5)$ & $8.7( \pm 0.8)$ & -4.054 & $<0.001^{*}$ \\
\hline Total density ${ }^{\#}$ & $2195.0( \pm 242.0)$ & $323.3( \pm 57.2)$ & -4.286 & $<0.001^{*}$ \\
\hline Plecoptera richness ${ }^{\circ}$ & $3.0( \pm 0.3)$ & $3.5( \pm 0.3)$ & -1.285 & $=0.199$ \\
\hline Plecoptera density & $327.9( \pm 102.9)$ & $153.5( \pm 39.0)$ & -1.815 & $=0.070$ \\
\hline Ephemeroptera richness $^{\circ}$ & $1.1( \pm 0.7)$ & $0.9(0.2)$ & -0.814 & $=0.415$ \\
\hline Ephemeroptera density ${ }^{\#}$ & $482.4( \pm 85.8)$ & $42.5( \pm 11.0)$ & -4.286 & $<0.001^{*}$ \\
\hline Trichoptera richness ${ }^{\circ}$ & $3.1(0.2)$ & $1.7( \pm 0.3)$ & -3.672 & $<0.001^{*}$ \\
\hline Trichoptera density ${ }^{\#}$ & $227.5( \pm 41.1)$ & $49.9( \pm 13.2)$ & -4.287 & $<0.001^{*}$ \\
\hline Coleoptera richness ${ }^{\circ}$ & $2.3(0.2)$ & $0.6( \pm 0.2)$ & -3.672 & $<0.001^{*}$ \\
\hline Coleoptera density & $164.2( \pm 39.8)$ & $15.7( \pm 5.1)$ & -4.247 & $<0.001^{*}$ \\
\hline Diptera richness ${ }^{\circ}$ & $2.9( \pm 0.7)$ & $1.4( \pm 0.2)$ & -3.993 & $<0.001^{*}$ \\
\hline Diptera density $\#$ & $918.1( \pm 153.3)$ & $56.0( \pm 12.5)$ & -4.286 & $<0.001^{*}$ \\
\hline
\end{tabular}

${ }^{\circ}$ Taxa $0.09 \mathrm{~m}^{-2}$; "individuals $\mathrm{m}^{-2}$; Ephemeroptera, Plecoptera and Trichoptera, genus level identification; Coleoptera and Diptera, family level identification; " significantly different. 
study streams dropped from an average of 482.4 individuals $\mathrm{m}^{-2}$ to less than 43 individuals $\mathrm{m}^{-2}$, a $91 \%$ reduction (Tab. 2). Trichopteran, coleopteran, and dipteran richness and density also significantly $(\mathrm{P}<0.001)$ dropped after the catastrophic storm event (Tab. 2).

Multivariate cluster analysis highlighted the similarities in benthic macroinvertebrate community composition and structure across study streams, with a $>60 \%$ similarity pre-catastrophic storm event (Fig. 4). After the catastrophic storm event, similarities in macroinvertebrate structure between streams dropped below 50\% (Fig. 4). Similarity profile tests highlighted significant differences between sites before and after the storm event on 24 October $(\mathrm{P}>0.05$ : SIMPROF), indicating a significant change in community composition and structure in all four study streams (Fig. 4.).

The mean SSRS and BMWP scores showed small decreases in site values, while the mean ASPT scores in- creased slightly (Tab. 3.) However, this resulted in no significant change in the ecological status of the sites following the storm event (Tab. 3).

\section{DISCUSSION}

The total daily rainfall at Casement Aerodrome on 24 October 2011 was calculated to be a one in twenty to one in twenty five year event, with the four hour period between 15.00 and $19.00 \mathrm{~h}$ equalled a one in eighty year event (Mac Cárthaigh, 2011). The hourly maximum of $23 \mathrm{~mm}$ recorded between 16.00 and $17.00 \mathrm{~h}$ was the highest hourly rainfall ever record for Casement Aerodrome (Mac Cárthaigh, 2011). Although the exact amounts of rainfall in the Wicklow Mountains at the time are difficult to calculate, they are likely to be greater than that at Casement Aerodrome (92 $\mathrm{m}$ asl) because of the effect of altitude (Yang, 2004), although the temporal pattern is most likely very similar.

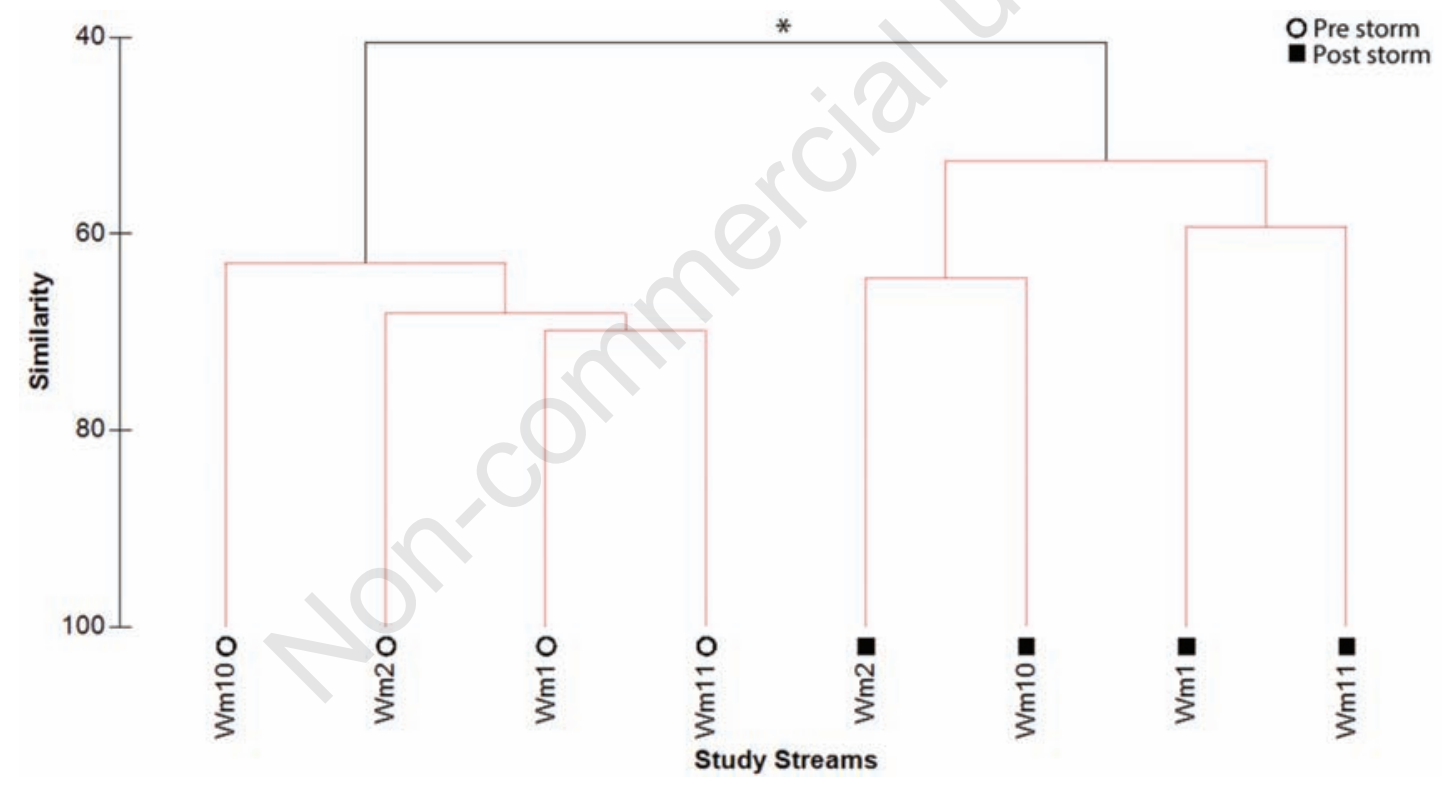

Fig. 4. The percentage similarity in the benthic macroinvertebrate community composition and structure of streams sampled before (pre) and after (post) the catastrophic storm event. Significant differences between groupings highlighted on the Cluster analysis dendogram using SIMPROF tests $(* \mathrm{P}<0.05)$. Only the means are shown on plots but all replicates were used in the analysis.

Tab. 3. Paired $t$-tests comparing the mean $( \pm \mathrm{SE})$ of selected bioassessment metric scores before (pre) and after (post) the catastrophic storm event on the $24^{\text {th }}$ of October 2011 in the Wicklow Mountains.

\begin{tabular}{lcccc}
\hline $\begin{array}{l}\text { Bioassessment } \\
\text { metric }\end{array}$ & $\begin{array}{c}\text { Pre-storm } \\
(\text { mean } \pm \text { SE) }\end{array}$ & $\begin{array}{c}\text { Post-storm } \\
(\text { mean } \pm \text { SE) }\end{array}$ & $\begin{array}{c}t \text { value } \\
(d f=3)\end{array}$ & P value \\
\hline SSRS & $8.2( \pm 0.7)$ & $8.0( \pm 0.9)$ & 0.397 & $=0.718$ \\
BMWP & $95.0( \pm 6.7)$ & $91.5( \pm 16.1)$ & 0.291 & $=0.790$ \\
ASPT & $6.0( \pm 0.2)$ & $6.5( \pm 0.3)$ & -1.190 & $=0.320$ \\
\hline
\end{tabular}

SSRS, Small Stream Risk Score; BMWP, Biological Monitoring Working Party; ASPT, Average Score Per Taxon. 
This is further supported by the water level data recorded in the Fraughan Brook (WM11) with maximum levels recorded at $17.00 \mathrm{~h}$, mirroring the period of highest rainfall recorded at Casement. The associated acidity $(\mathrm{pH} \sim 4.5)$ was typical of episodic events known to occur in the Wicklow Mountains (Kelly-Quinn et al., 1996, 1997, 2008).

The impact of this catastrophic event on the benthic macroinvertebrate communities of the four study streams was similar to findings elsewhere, with the severe loss of macroinvertebrate richness and densities across all functional groups (Giller et al., 1991; Boulton and Lake, 1992; Angradi, 1997; Lake, 2000). During this study the prestorm community structure across the sites was typical of episodic acid streams in the Wicklow Mountains (Tierney et al., 1998; Kelly-Quinn et al., 2008; Feeley et al., 2011, 2012). The significant loss of macroinvertebrate taxa during the storm probably resulted from the combined effect of high water level (and associated high flow), low $\mathrm{pH}$, abrasion and movement of instream substrates and associated physical disturbance. The toxic effects associated with acidic conditions cause stress on sensitive macroinvertebrate biota, resulting in the drifting of taxa (e.g. Ephemeroptera) which is known to have a detrimental effect on population composition and structure (Ormerod et al., 1989; Kowalik and Ormerod, 2006). However, physical disturbance and wash-out of biota are likely to have played a more significant role in the changes captured during this study. Physical upheaval and disturbance resulting from high flow causes the streambed sediment to break up, allowing entrainment (i.e. the picking up and setting into motion) and abrasion of surface and subsurface substrates within and adjacent to the stream (Andrews, 1984; Andrews and Nankervis, 1995). Prior to the storm event on 24 October the instream habitats of the four sites were characterised by short riffle-run sequences, interspersed with shallow pools and were generally dominated by cobbles with some coarse gravel, sand and scattered large boulders, which is typical of small upland headwater streams in Ireland (Callanan et al., 2008; Feeley et al., 2012). The entrainment disturbance caused during the catastrophic event altered the natural sequence of instream habitats, causing severe damage to both the streambeds and banks in the four streams with the substrate composition changing to predominantly boulder and sand. This would have decreased the overall habitat heterogeneity. Instream vegetation was also visually reduced. A previous study by Englund (1991) showed that such stream disturbances have detrimental effects on stream moss, reducing the biomass and affecting species composition. In addition, during this study many benthic macroinvertebrate groups showed significant reductions in densities most likely as a result of the physical disturbance, since acid-tolerant benthic macroinvertebrate taxa, such as Siphlonurus, Ameletus and Plectrocnemia were also severely affected and ephemeropteran (acid-sensitive) richness was not notably reduced. The physical disturbance almost certainly caused extensive shifts in patches of unstable/destabilised sediment during the increased discharge, with large-scale invertebrate drift/loss across the community. Macroinvertebrates loss has been strongly linked to substrate movement as individuals shift out of the rising channel and are washed away and/or crushed by moving substrate and debris (Brittain and Eikeland, 1988; Death, 2008; Gibbons et al., 2010).

The combination of factors associated with the storm event altered the overall community composition and structure significantly. The Plecoptera were the only macroinvertebrate group to escape major change, with richness increasing slightly, although densities suffered losses of $54 \%$ in overall numbers. Similarly, ephemeropteran richness also remained unaffected, while densities were significantly reduced. The Trichoptera, Coleoptera and Diptera also suffered significant reductions in both richness and density within all four streams sampled. Although, some of the changes in composition are likely to be seasonal, with several taxa (e.g. Siphlonurus sp.) emerging as adults in mid to late autumn and other taxa (e.g. Ameletus sp.) having hatched during the same period, the fact the taxonomic resolution was predominantly at genus and family level indicates a severe level of impact on the overall community. The impact recorded would likely have been greater if species level identification had been utilised for all macroinvertebrate groups. Furthermore, the period of September through November is the principal recruitment/egg hatching period of many benthic macroinvertebrates in Ireland and elsewhere, especially the Plecoptera, Ephemeroptera and Trichoptera (Hynes, 1977; Crichton et al., 1978; Edington and Hildrew, 1995; Smith et al., 2000; Feeley et al., 2009; Elliott and Humpesch, 2010; McCarty, 2010). Although this was observed for plecopteran richness, the richness and density of the other macroinvertebrate groups should have, in theory, increased, or at least been maintained, rather than decreased during the study period.

The greatest heterogeneity of macroinvertebrate communities in riverine systems in Ireland generally occurs within the headwaters (Callanan, 2009; Feeley and KellyQuinn, 2012). The effects of large disturbances, such as massive storm events, vary from species to species and from habitat to habitat leading to higher heterogeneity within affected stream communities (Reice, 1985; Resh et al., 1988; Townsend et al., 1997; Schwendel et al., 2011b). A decrease in percentage similarity in community composition and structure among the sampled sites was seen post storm, indicating an increase in taxonomic heterogeneity amongst the affected sites. Although not directly compared, the impact on macroinvertebrate communities did not vary with landuse. Previous research 
throughout North Western Europe found little difference in peak flows recorded in moorlands and forested streams (Robinson et al., 2003).

An awareness of the effects of such massive storms is important when one is determining ecological status. The three bioassessment metrics used during this study showed no overall change in the ecological status of the study sites post storm. This most likely relates to the lack of any organic pollution and the maintenance of both Plecoptera and Ephemeroptera richness which helps preserve the metric values. This is an important finding and suggests that these metrics, at least in clean water systems, are unaffected by significant flooding. The catastrophic losses of macroinvertebrate densities demonstrate that there clearly was significant alteration to the macroinvertebrate composition and structure of examined streams. It is, therefore, vital that metrics are developed or altered to take account of dramatic losses in densities/abundances of taxa, such as that developed by Schwendel et al. (2011b) for assessing streambed stability in New Zealand's North Island.

Catastrophic flooding of the type described in this study has potential implications for site recovery and thus, regional biodiversity, particularly if such events are as spatially widespread as this storm (Mac Cárthaigh, 2011) and were to become a more common occurrence as predicted due to climate change (see McElwain and Sweeney, 2007; Sweeney et al., 2008). Such catastrophic events with major depletions within a system(s) are likely to affect the resource pool for recolonisation and in some instances may actually result in species exhaustion (Giller et al., 1991; Gibbons et al., 2010). If frequent physical disturbances occur, it possibly limits benthic macroinvertebrate recovery, both directly through continuous/frequent streambed destabilisation, reduced habitat heterogeneity, loss of critical life cycle stages and refugia and/or competitive exclusion, or indirectly through the alteration of the food resource and vegetation structure of the stream (Townsend et al., 1997; Robinson and Minshall, 1986; Tixier et al., 2009; Schwendel et al., 2011a). Therefore, the significant disturbance, and loss of both taxonomic richness and density, if recurrent, will have major implications for the maintenance of healthy macroinvertebrates populations, and thus ecological diversity within affected headwaters. The downstream persistence and effects of such large storms on the surface water hydrology and ecology are inextricable related to the changes in flow and magnitude of bedrock/sediment scouring, entrainment and transport, which vary with catchment size (Richards et al., 2001; Jakob et al., 2003). Consequently, the ability of any taxonomic groups within affected watercourses to resist the effects of a major disturbance depends on several biotic and abiotic factors. Such factors include the stability of instream habitat, the attachment/burrowing ability of taxa and the effective use of refugia and flexible/plastic life history strategies (Giller et al., 1991; Palmer et al., 1996; Tixier et al., 2009).

\section{CONCLUSIONS}

Catastrophic storm events in upland headwater streams can severely alter macroinvertebrate composition and structure, with major losses in the densities of all taxonomic groups. The resultant losses may have long term implications as many studies have indicated the slow and often poor recovery of macroinvertebrate communities (Giller et al., 1991; Gibbons et al., 2010). Regardless, the recovery of the natural taxonomic richness, density, and community composition and structure post major disturbance is a function of the magnitude of any impact and is therefore likely to be both time and site specific (Wallace, 1990; Death, 2008). For example, Giller et al. (1991) found season to be a factor, with winter invertebrates much more resilient to disturbance compared to summer taxa due to life cycle disruption of summer taxa and the adaptability of winter taxa. However, any recovery of benthic macroinvertebrate groups is reliant on several factors such as the utilisation of instream refugia, survival in the drift (i.e. safe resettlement), life cycle dynamics and recolonisation sources (Giller et al., 1991; Palmer et al., 1996; Tixier et al., 2009).

Ultimately, such massive impacts and the potential slow recovery may have major implications for future stream diversity. Several studies highlight the importance of individual small headwater streams to regional diversity in Ireland, the UK and the US (Minshall et al., 1985; Minshall and Robinson, 1998; Furse, 2000; Callanan, 2009; Feeley and Kelly-Quinn, 2012). Given the spatial influence of this storm event (Mac Cárthaigh, 2011), the level of impact across all four study sites, and the high number of small headwater streams in the Wicklow Mountains, the potential impact as a result of such catastrophic storms on the regional macroinvertebrate populations is high, possibly reducing local recolonisation sources and thus, conceivably limiting the ability of affected streams to maintain at least good quality waters as prescribed by the Water Framework Directive (European Parliament and Council, 2000).

\section{ACKNOWLEDGEMENTS}

The data derived for this paper were collected as part of the HYDROFOR project co-sponsored by the Department of Agriculture, Food and the Marine, and the Environmental Protection Agency under the STRIVE Program 2007 - 2013. Thanks to Mr. John Clarke, Dr. Nuala Freeman and Dr. Heather Lally for their assistance during this study. Thank you to the two anonymous reviewers for their helpful comments and insightful suggestions. 


\section{REFERENCES}

Andrews ED, 1984. Bed-material entrainment and hydraulic geometry of gravel-bed rivers in Colorado. Geol. Soc. Am. Bull. 95:371-378.

Andrews ED, Nankervis JM, 1995. Effective discharge and the design of channel maintenance flows for gravel-bed rivers. In: J.E. Costa, A.J. Miller, K.W. Potter and P.R. Wilcock (eds.) Natural and anthropogenic influences in fluvial geomorphology. Geophys. Monogr. 89: 151-164.

Angradi TR, 1997. Hydrologic context and macroinvertebrate community response to floods in an Appalachian headwater stream. Am. Midl. Nat. 138: 371-386.

Anonymous, 2005. Western river basin district project: small streams risk score. Environmental Protection Agency, Ireland.

Boulton AJ, Lake PS, 1992. The ecology of two intermittent streams in Victoria, Australia. Temporal changes in faunal composition. Freshwater Biol. 27: 123-138.

Brittain J, Eikeland TJ, 1988. Invertebrate drift - a review. Hydrobiologia 166: 77-93.

Callanan M, Baars J-R, Kelly-Quinn M, 2008. Critical influence of seasonal sampling on the ecological quality assessment of small headwater streams. Hydrobiologia 610: 245-255.

Callanan MC, 2009. An investigation of the macroinvertebrate communities of Irish headwater streams. Ph.D. thesis, National University of Ireland, Dublin.

Clarke KR, Gorley RN, 2006. PRIMER v6: User manual/tutorial. PRIMER-E Ltd., Plymouth.

Crichton MI, Fisher D, Woiwod IP, 1978. Life histories and distribution of British Trichoptera, excluding Limnephilidae and Hydroptilidae, based on the Rothamsted Insect Survey. Holartic Ecol. 1: 31-45.

Death RG, 2003. Spatial patterns in lotic invertebrate community composition: is substrate disturbance actually important? Can. J. Fish. Aquat. Sci. 603: 603-611.

Death RG, 2008. The effect of floods on aquatic invertebrate communities, p. 103-121. In: J. Lancaster and R.A. Briers (eds.), Aquatic insects: challenges to populations. CAB International, Wallingford.

Edington JM, Hildrew AG, 1995. A revised key to the caseless caddis larvae of the British Isles, with notes on their ecology. Scientific Publication No. 53, Freshwater Biological Association, Cumbria, p. 134.

Englund G, 1991. Effects of disturbance on stream moss and invertebrate community structure. J. N. Am. Benthol. Soc. 10: 143-153.

Elliott JM, Humpesch UH, 2010. Mayfly Larvae (Ephemeroptera) of Britain and Ireland: keys and a review of their ecology. Scientific Publication No. 66, Freshwater Biological Association, Cumbria, p. 152.

European Parliament and Council, 2000. Annex V Directive 2000/60/EC of the European Parliament and of the Council of 23 October 2000 establishing a framework for Community action in the field of water policy. Official Journal of the European Communities, L327: 1-73.

Feeley H, Baars J-R, Kelly-Quinn M, 2009. The life history of Perla bipunctata Pictet, 1833 (Plecoptera; Perlidae) in the upper River Liffey. Aquat. Insects 31: 261-270.

Feeley HB, Kelly-Quinn M, 2012. An evaluation of local and regional diversity of benthic macroinvertebrate communities in two small regions of Ireland and their potential as localised refugia for certain taxonomic groups. Biol. Environ. 112B: 43-54.

Feeley HB, Kerrigan C, Fanning P, Hannigan E, Kelly-Quinn M, 2011. Longitudinal extent of acidification effects of plantation forest on benthic macroinvertebrate communities in soft water streams: evidence for localised impact and temporal ecological recovery. Hydrobiologia 671: 217-226.

Feeley HB, Woods M, Baars J-R, Kelly-Quinn M, 2012. Refining a kick sampling strategy for the bioassessment of benthic macroinvertebrates in headwater streams. Hydrobiologia 683: 53-68.

Furse MT, 2000. The application of RIVPACS procedures in headwater streams-an extensive and important national resource, p. 79-91. In: J.F. Wright, D.W. Sutcliffe and M.T. Furse (eds.), Assessing the biological quality of freshwaters. RIVPACS and Other Techniques, Freshwater Biological Association, Cumbria.

Gibbons C, Batalla RJ, Vericat D, 2010. Invertebrate drift and benthic exhaustion during disturbance: response of mayflies (Ephemeroptera) to increasing shear stress and river-bed instability. River Res. Appl. 26: 499-511.

Giller PS, Sangpradub N, Twomey H, 1991. Catastrophic flooding and macroinvertebrate community structure. Verh. Int. Ver. Theor. Angew. Limnol. 24: 1724-1729.

Haase P, Murray-Bligh J, Lohse S, Pauls S, Sundermann A, Gunn R, Clarke R, 2006. Assessing the impact of error in sorting and identifying macroinvertebrate samples. Hydrobiologia 566: 505-521.

Hawkes HA, 1997. Origin and development of the biological monitoring working party score system. Water Res. 32: 964968.

Hynes HBN, 1977. A key to the adult and nymphs of the British stoneflies (Plecoptera) with notes on their ecology and distribution, p. 1-92. Scientific Publication No. 66, Freshwater Biological Association, Cumbria.

IBM SPSS, 2010. SPSS software. Predictive analytics software and solutions. Chicago, IL.

Jakob C, Robinson CT, Uehlinger U, 2003. Longitudinal effects of experimental floods on stream benthos downstream from a large dam. Aquat. Sci. 65: 223-231

Kavanagh P, Walsh R, Walsh A, 2006. Further characterisation of small streams and development of a new small stream risk score (SSRS) project output report. ESB International Ltd., Dublin: 46 pp.

Kelly-Quinn M, Cruikshanks R, Johnson J, Matson R, Baars JR, Bruen M, 2008. Forestry and Surface-water Acidification (FORWATER), p. 1-81. Report to the Western River Basin District. Available from: http://www.wfdireland.ie/docs/ 22 ForestAndWater/

Kelly-Quinn M, Tierney D, Coyle C, Bracken JJ, 1996. Factors affecting the susceptibility of Irish soft-water streams to forest-mediated acidification. Fisheries Manag. Ecol. 3: 287301.

Kelly-Quinn M, Tierney D, Coyle C, Bracken JJ, 1997. AQUAFOR Report 3: Stream chemistry, hydrology and biota, Wicklow region, p. 1-95. In: AQUAFOR Report Vol. 3 , A study of the effects of stream hydrology and water quality in forested catchments on fish and invertebrates. COFORD, Dublin. 
Kowalik RA, Cooper DM, Evans CD, Ormerod SJ, 2007. Acidic episodes retard the biological recovery of upland British streams from chronic acidification. Global Change Biol. 13: 2439-2452.

Kowalik RA, Ormerod SJ, 2006. Intensive sampling and transplantation experiments reveal continued effects of episodic acidification on sensitive stream invertebrates. Freshwater Biol. 51: 180-191.

Lake PS, 2000. Disturbance, patchiness and diversity in streams. J. N. Am. Benthol. Soc. 19: 573-592.

Lepori F, Barbieri A, Ormerod SJ, 2003. Effects of episodic acidification on macroinvertebrate assemblages in Swiss Alpine streams. Freshwater Biol. 48: 1873-1885.

Mac Cárthaigh M, 2011. A preliminary assessment of the flooding which occurred on 24 October 2011 in selected catchments on the east coast, based on data collected at the EPA-LA hydrometric stations. Dublin Regional Inspectorate, Environmental Protection Agency, Dublin 14: 25 pp.

McCabe DJ, Gotelli NJ, 2000. Effects of disturbance frequency, intensity, and area on assemblages of stream macroinvertebrates. Oecologia 124: 270-279.

McCarthy S, 2010. The autecology of selected ephemeropteran species in Irish rivers. Ph.D. thesis, National University of Ireland, Dublin.

McElwain L, Sweeney J, 2007. Key meteorological indicators of climate change in Ireland. Environmental Protection Agency, Wexford: $31 \mathrm{pp}$.

Minshall GW, Petersen RC, Nimz CF, 1985. Species richness in streams of different size from the same drainage basin. Am. Nat. 125: 16-38.

Minshall GW, Robinson CT, 1998. Macroinvertebrate community structure in relation to measures of lotic habitat heterogeneity. Arch. Hydrobiol. 141: 129-151.

Ormerod SJ, Boole P, McMahon CP, Weatherley NS, Pascoe D, Edwards RW, 1987. Short-term experimental acidification of a Welsh stream: comparing the biological effects of hydrogen ions and aluminium. Freshwater Biol. 17: 341-356.

Ormerod SJ, Donald AP, Brown SJ, 1989. The influence of plantation forestry on the $\mathrm{pH}$ and aluminium concentration of upland welsh streams: a re-examination. Environ. Poll. 62: 47-62.

Palmer MA, Arensburger P, Martin AP, Denman DW, 1996. Disturbance and patch-specific responses: the interactive effects of woody debris and floods on lotic invertebrates. Oecologia 105: 247-257.

Reice SR, 1985. Experimental disturbances and the maintenance of species diversity in a stream community. Oecologia 67: 90-97.

Resh VH, Brown AV, Covich AP, Gurtz ME, Li HW, Minshall GW, Reice SR, Sheldon AL, Wallace JB, Wissmar RC, 1988. The role of disturbance in stream ecology. J. N. Am. Benthol. Soc. 7: 433-455.

Richards PR, Baker DB, Kramer JW, Ewing DE, Merryfield BJ, Miller, NL, 2001. Storm discharge loads and average concentrations in Northwest Ohio rivers 1975-1995. J. Am.
Water. Resour. As. 37: 423-438.

Robinson M, Cognard-Plancq A-L, Cosandey C, David J, Durand $\mathrm{P}$, Führer H-W, Hall R, Hendriques MO, Marc V, McCarthy R, McDonnell M, Martin C, Nisbet T, O' Dea P, Rodgers M, Zollner A, 2003. Studies of the impact of forests on peak flows and baseflows: a European perspective. Forest Ecol. Manag. 186: 85-97.

Robinson CT, Minshall GW, 1986. Effects of disturbance frequency on stream benthic community structure in relation to canopy and season. J. N. Am. Benthol. Soc. 5: 237-248.

Schwendel AC, Death RG, Fuller IC, Joy MK, 2011a. Linking disturbance and stream invertebrate communities: how best to measure bed stability. J. N. Am. Benthol. Soc. 30: 11-24.

Schwendel AC, Joy MK, Death RG, Fuller IC, 2011b. A macroinvertebrate index to assess stream-bed stability. Mar. Freshwater Res. 62: 30-37.

Smith C, Good M, Murphy JF, Giller PS, O'Halloran J, 2000. Life-history patterns and spatial and temporal overlap in an assemblage of lotic Plecoptera in the Araglin Catchment Study Area, Ireland. Arch. Hydrobiol. 150: 117-132.

Snyder CD, Johnson ZB, 2006. Macroinvertebrate assemblage recovery following a catastrophic flood and debris flows in an Appalachian Mountain stream. J. N. Am. Benthol. Soc. 25: 825-840.

Sweeney J, Albanito F, Breteton A, Caffarra A, Charlton R, Donnelly A, Fealy R, Fitzgerald J, Holden N, Jones M, Murphy C, 2008. Climate change - Refining the impacts for Ireland. Environmental Protection Agency, Wexford: 163 pp.

Tierney D, Kelly-Quinn M, Bracken JJ, 1998. The faunal communities of upland streams in the eastern region of Ireland with reference to afforestation impacts. Hydrobiologia 389: 115-130.

Tixier G, Felten V, Guérold F, 2009. Life cycle strategies of Baetis species (Ephemeroptera, Baetidae) in acidified streams and implications for recovery. Fund. Appl. Limnol. 174/3: 227-243.

Tixier G, Guérold F, 2005. Plecoptera response to acidification in several headwater streams in the Vos Mountains (northeastern France). Biodivers. Conserv. 14: 1525-1539.

Townsend CR, 1989. The patch dynamics concept of stream community ecology. J. N. Am. Benthol. Soc. 8: 36-50.

Townsend CR, Scarsbrook MR, Dolèdec S, 1997. The intermediate disturbance hypothesis, refugia and biodiversity in streams. Limnol. Oceanogr. 42: 938-949.

Turner MG, Dale VH, 1998. Comparing large, infrequent disturbances: what have we learned? Ecosystems 1: 493-496.

Wallace JB, 1990. Recovery of lotic macroinvertebrate communities from disturbance. Environ. Manag. 14: 605-620.

Weatherley NS, Ormerod SJ, 1991. The importance of acid episodes in determining faunal distributions in Wales. Freshwater Biol. 25: 71-84.

Yang J, 2004. Development and evaluation of computer models for flood simulation and forecasting in urban areas. Ph.D. thesis, National University of Ireland, Dublin. 